\title{
ADJECTIVE CHECK LIST PENGUNGKAP STEREOTIP LAKI-LAKI DAN PEREMPUAN MENURUT PERSEPSI MAHASISWA DARI SEPULUH ETNIS
}

\author{
Wening Sahayu \\ Fakultas Bahasa dan Seni Universitas Negeri Yogyakarta \\ email: wenweni88@yahoo.com
}

\begin{abstract}
This study aims to describe male and female stereotypes based on the perceptions of students from ten ethnic groups in Indonesia and agreed upon by all of them and to compare such stereotypes with the research findings by Best and William. The respondents were students from ten ethnic groups, i.e. Jawa, Papua, Sunda, Bali, Madura, Lombok, Batak, Minangkabau, Aceh, dan Betawi. The survey employed a questionnaire with fifty adjectives representing characters referring to the study by Best and William. The data were descriptively analyzed using tabulation and percentage. The findings are as follows. First, students from each ethnic group have a variety of perceptions regarding male and female stereotypes agreed upon. Second, there are a number of male and female stereotypes agreed upon by students from all ethnic groups. Third, the male stereotypes relevant to the study by Best and Williams are strength, dominance, autonomy, and aggression. The female stereotypes relevant to both studies are passiveness, weakness, and abasement.
\end{abstract}

Keywords: stereotype, adjective, perception

\section{PENDAHULUAN}

Penelitian mengenai gender di Indonesia dapat dikatakan masih relatif baru, dibandingkan penelitian sejenis yang dilakukan di negara-negara lain seperti Amerika, Australia, Jerman, Belanda dan negara maju yang lainnya. Pada kenyataannya, penelitian mengenai gender tidak hanya berkaitan dengan permasalahan kegenderan itu sendiri. Hal yang tak kalah penting dan menjadi ukuran keberhasilan dalam penelitian gender adalah populasi penelitian. Di beberapa negara maju, yang menjadi sampel dan populasi dalam penelitian gender telah jamak tersebar hingga di luar suatu negara dimana penelitian tersebut dilakukan. Salah satu penelitian mengenai gender yang diakui kredibilitasnya dilakukan oleh Deborah L. Beest dan John E. Williams. Tema penelian ini adalah mengenai stereotip laki-laki dan perempuan menurut masyarakat di dua puluh lima negara, yang menjangkau lima benua. Benua Asia diwakili oleh Taiwan, Thailand, Malaysia, Japan, dan India. Indonesia tidak diikutseratakan sebagai sampel penelitian ini. Untuk menjaring data yang dibutuhkan, digunakan kuesioner yang berisi tiga ratus ajektiva yang berkaitan dengan karakter dan perilaku manusia. Dalam dunia gender, instrument yg terdiri dari tiga ratus buah ajektiva ini dikenal dengan sebutan The Adjecktive Check List (ACL) yang merupakan hasil karya Gough dan Heilbrun (1980). Kuesioner ini didistribusikan melalui internet. Responden disuruh memilih ajektiva yang tepat untuk mewakili masing-masing karakter dan perilaku laki-laki dan perempuan. Hasil penelitian ini adalah bahwa semua responden menyetyjui bahwa terdapat perbedaan stereotip antara laki- 
laki dan perempuan. Stereotip laki-laki adalah strong dan active. Adapun stereotip perempuan adalah passive dan weak. Temuan ini merupakan sesuatu yang sensasional, karena pada kenyataannya di belahan dunia manapun selalu digembargemborkan mengenai kesetaraan gender. Salah satu tujuan dari para penggiat kesetaraan gender adalah menepis persepsi yang tumbuh di masyarakat yang menstereotip wanita dalam kategori passive dan weak.

Kegiatan penstereotipan atau pelabelan berkaitan dengan sosia kultural suatu masyarakat (Abu, 2003). Latar belakang etnis merupakan salah satu faktor yang mempengaruhi penstereotipan ini. Hubungan antara kedua hal ini dapat dilihat dari konsep 'konco wingking' yang diproduksi oleh masyarakat dari etnis Jawa (Fakih, 2003). Terjemahan harfiah dari 'konco wingking' adalah teman belakang. Dalam masyarakat Jawa, yang memiliki 'konco wingking' adalah laki-laki yang sudah beristri. Adapun yang diposisikan sebagai 'konco wingking' adalah perempuan, yang telah menjadi istri laki-laki tersebut. Menurut konsep kesetaraan gender, keadaan ini merefleksikan adanya diskriminasi terhadap eksistensi perempuan. Pada konsep 'konco wingking' ini dikesankan bahwa laki-laki lebih layak menjadi pemimpin daripada perempuan. Selain itu, dalam konsep 'konco wingking' ini laki-laki selalu dijadikan parameter atas terbentuknya suatu relasi suami - istri.

Persepsi adalah ekspresi manusia terhadap segala hal yang ada di masyarakatnya. Ekspresi ini merupakan cara merealisasikan rasa atau pikiran terhadap segala hal yang ada di masyarakat. Persepsi seseorang ataupun sekelompok masyarakat memiliki peran penting dalam kaitannya dengan aktualisasi perilaku seseorang sebagai anggota masyarakat dalam kehidupan seharihari (Gula, 1982). Sapir dan Whorf (da- lam Wardaugh, 1990) mengungkapkan bahwa perilaku dalam masyarakat ditentukan oleh persepsi masyarakat mangenai konteks kehidupan yang dijalaninya dalam keseharian. Demikian halnya, perilaku yang berbeda antara laki-laki dan perempuan dalam masyarakat juga ditentukan oleh persepsi mengenai stereotip laki-laki dan perempuan. Dengan label yang dilekatkan pada laki-laki dan perempuan oleh anggota masyarakat yg melakukan penstereotipan atau pelabelan tersebut, menjadi salah satu sebab dibedakannya perlakuan masyarakat terhadap laki-laki dan perempuan. Selain itu, penstereotipan yang terjadi di masyarakat dari waktu ke waktu, secara langsung atau tidak, dan disadari atau tidak diwariskan dari generasi ke generasi. Dengan demikian, bukan lagi hal yang muskil jika para generasi muda dari etnis mana saja sampai sekarang ini memiliki persepsi mengenai stereotip laki-laki dan perempuan. Mahasiswa sebagai salah satu kelompok generasi muda dimungkinkan memiliki persepsi tersendiri mengenai stereotip laki-laki dan perempuan. Banyak faktor yang bisa memunculkan perbedaan persepsi yang dimiliki oleh mahasiswa di Indonesia, antara lain latar belakang keluarga, etnis, ideologi, dan lain sebagainya. Perbedaan persepsi tersebut bisa berarti hanya merupakan perubahan kategori dalam penstereotipan laki-laki dan perempuan dalam masyarakat. Namun demikian, tetap ada kemungkinan perbedaan persepsi yang muncul justru meminimalkan perbedaan perlakuan terhadap laki-laki dan perempuan di masyarakat.

Bahasa tidak hanya bisa diartikan sebagai sarana komunikasi antar manusia dalam masyarakat. Bahasa juga merupakan rekaman kebudayaan suatu etnis atau bangsa. Bahasa merupakan hasil kebudayaan. Segala sesuatu yang terjadi, dipikirkan, dilakukan oleh masyarakat 
dalam perjalanan hidupnya direfleksikan dalam bahasa yang tumbuh dalam masyarakat tersebut (Poedjosoedarmo, 2010). Pendapat ini sejalan dengan Sapir dan Whorf (dalam Wardaugh, 1990), bahwa perilaku kita dalam masyarakat ditentukan oleh persepsi masyarakat tentang keadaan atau fakta yang ada, dan keadaan atau fakta ini ditentukan dan direfleksikan melalui bahasa. Salah satu keadaan yang ditemui dalam kehidupan masyarakat adalah pelabelan atau penstereotipan masyarakat terhadap laki-laki dan perempuan. Dari pendapat di atas dapat disimpulkan bahwa bahasa dapat menjadi petunjuk atau pengungkap steretip laki-laki dan perempuan yang dilakukan oleh masyarakat. Terkait dengan penelitian ini, bahasa yang dimaksud sebagi alat penunjuk atau pengungkap stereotip laki-laki dan perempuan berwujud ajektiva. Ajektiva tersebut berkaitan dengan karakter dan perilaku manusia. Ajektiva semacam ini sudah disusun oleh Gough dan Heilbrun (Bart,1993) dan dikenal dengan sebutan The Adjective Check List (ACL) .

\section{METODE}

Penelitian ini terinspirasi oleh penelitian Deborah L. Beest dan John E. William mengenai stereotip laki-laki dan perempuan. Responden dalam penelitian ini adalah mahasiswa yang berasal dari etnis Jawa, Sunda, Bali, Madura, Lombok, Batak, Minangkabau, Papua, Aceh, dan Betawi. Mahasiswa tersebut sedang menempuh kuliah di UNJ, UI, UNY, UGM, STPMD, JANABADRA, UM, dan UMM. Responden dari masing-masing kelompok etnis terdiri dari lima puluh orang.

Data dijaring melalui kuesioner yang diberikan pada responden. Selanjutnya, responden disuruh mencocokkan sejumlah ajektiva (sebanyak lima puluh buah, yang juga digunakan oleh Beest dan William) yang menurut persepsi mereka cocok dengan karakter atau perilaku laki-laki atau perempuan. Data dianalisis secara deskriptif dengan menggunakan tabulasi data dan presentase.

Permasalahan yang ingin diurai dalam penelitian ini dapat dirumuskan: (1) bagaimana stereotip laki-laki dan perempuan menurut persepsi mahasiswa dengan latar belakang etnis Jawa, Sunda, Bali, Madura, Lombok, Batak, Minangkabau, Papua, Aceh, dan Betawi (2) bagaimana stereotip laki-laki dan perempuan yang disetujui oleh mahasiswa dari semua etnis (3) stereotip laki-laki dan perempuan yang manakah yang sama dengan hasil penelitian yang dilakukan Beest dan Williams.

Hasil penelitian ini diharapkan dapat memperkaya teori mengenai gender, khususnya mengenai stereotip lakilaki dan perempuan menurut persepsi mahasiswa dari etnis Jawa, Sunda, Bali, Madura, Lombok, Batak, Minangkabau, Papua, Aceh, dan Betawi. Hasil penelitian juga dapat dimanfaatkan sebagai referensi, dokumentasi, dan inspirasi untuk melakukan penelitian lanjutan. Secara teoritis.

\section{HASIL DAN PEMBAHASAN Stereotip Laki-Laki dan Perempuan Menurut Persepsi Mahasiswa Tiap Et- nis}

Berdasarkan persepsi mahasiswa dari etnis Papua, terdapat sejumlah stereotip yang diposisikan untuk wanita dan sejumlah yang lain diposisikan untuk laki-laki, sebagai berikut. Pertama, setereotip untuk perempuan: active, exhibition, endurance, passive, weak, adapted, child, abasement, succorance, favorability, order, appreciative, gentle, softhearted, changeable, meek, affectionate, dependent, complaining, fussy, talk active. Kedua, stereotip untuk laki-laki: strong, critical parent, adult, dominance, autonomy, ag- 
gression, achievement, free child, deference, affiliation, coarse, adventurous, cruel, disorder, loud, independent, heterosexual, boastful, severe, enterprising, confident, logical, jolly, steady, affected, interception, flirtatious, frivolous, excitable.

Berdasarkan persepsi mahasiswa dari etnis Mnangkabau, terdapat sejumlah stereotip yang diposisikan untuk wanita dan sejumlah yang lain diposisikan untuk laki-laki, sebagai berikut. Pertama, setereotip untuk perempuan: critical parent, exhibition, endurance, passive, weak, nurturing parent, adapted child, abasement, favorability, order, appreciative, softhearted, changeable, meek, affectionate, dependent, complaining, fussy, talk, active, frivolous. Kedua, stereotip untuk laki-laki: strong, critical parent, adult, dominance, autonomy, aggression, achievement, free child, deference, affiliation, coarse, adventurous, cruel, disorder, loud, independent, heterosexual, boastful, severe, enterprising, confident, logical, jolly, steady, affected, interception, flirtatious, frivolous, excitable.

Berdasarkan persepsi mahasiswa dari etnis Bali, terdapat sejumlah stereotip yang diposisikan untuk wanita dan sejumlah yang lain diposisikan untuk laki-laki, sebagai berikut. Pertama, stereotip untuk perempuan: achievement, adult,succorrance, boasful, heterosex, jolly, gentle, critical parent, exhibition, endurance, passive, weak, nurturing parent, adapted child, favorability, order, appreciative, softhearted, changeable, meek, affectionate, complaining, fussy, talk active. Kedua, stereotip untuk laki-laki: strong, active, adult, dominance, autonomy, aggression, free child, deference, affiliation, coarse, adventurous, cruel, disoder, loud, independent, heterosexsual, severe, enterprising, confident, logical, jolly, steady, affected, interception, flirtatious, frivolous, excitable.

Berdasarkan persepsi mahasiswa dari etnis Sunda, terdapat sejumlah stereotip yang diposisikan untuk wanita dan sejumlah yang lain diposisikan un- tuk laki-laki, sebagai berikut. Pertama, tereotip untuk perempuan: : achievement, critical parent, adult, exhibition, endurance, passive, weak, nurturing, parent, adapted child, succourance, heterosex, boasul, jolly, gentle, abasement, favorabilty, order, softhearted, changeable, meek, affectionate, dependent, complaining, fussy, talk active, frivolous. Kedua, stereotip untuk lakilaki: strong, active, dominance, autonomy, aggression, free child, deference, affilation, coarse, adventurous, cruel, disoder, loud, independent, severe, enterprising, confident, logical, steady, affected, appreciative, flirtatious, affected, inraception, excitable.

Berdasarkan persepsi mahasiswa dari etnis Lombok, terdapat sejumlah stereotip yang diposisikan untuk wanita dan sejumlah yang lain diposisikan untuk laki-laki, sebagai berikut. Pertama, setereotip untuk perempuan: achievement, critical parent, exhibition, endurance, passive, weak, free child, abasement, heterosex, boasful, appriciative, jolly, gentle, favorability, order, softhearted, changeable, meek, affectionate, dependent, complaining, fussy, talk active, frivolous. Kedua, stereotip untuk laki-laki: achievement, strong, adult, dominance, autonomy, aggression, free child, deference, succorance, affiliation, coarse, adventurous, cruel, disoder, loud, severe, enterprising, confident, logical, steady, affected, interception, flirtatious, dependent, frivolous, excitable.

Berdasarkan persepsi mahasiswa dari etnis Batak, terdapat sejumlah stereotip yang diposisikan untuk wanita dan sejumlah yang lain diposisikan untuk laki-laki, sebagai berikut. Pertama, setereotip untuk perempuan: critical parent, exhibition, endurance, passive, weak, jolly, gentle, favorabilty, order, appriciative, softhearted, changeable, meek, affectionate, dependent, complanining, fussy, talk active, frivolous. Kedua, stereotip untuk laki-laki: strong, active, dominance, autonomy, aggression, achievement, free child, deference, succorance, affilation, coarse, adventurous, 
cruel, disoder, loud, independent, boasful, severe, interprising, confident, logical, steady, affected, interception, flirtatious, excitable.

Berdasarkan persepsi mahasiswa dari etnis Aceh, terdapat sejumlah stereotip yang diposisikan untuk wanita dan sejumlah yang lain diposisikan untuk laki-laki, sebagai berikut. Pertama, setereotip untuk perempuan: critical parent, exhibition, endurance, passive, weak adapted child, abasement, succorance, jolly, gentle, heterosex, boasful, order, favorabilty, order, appreciative, softhearted, changeable, meek, affectionate, dependent, complaining, fussy, talk active. Kedua, stereotip untuk laki-laki: strong, adult, dominance, autonomy, aggression, achevement, free child, deference, succorance, coarse, adventurous, cruel, disoder, loud, independent, severe, interprising, confident, logical, jolly, steady, affected, interception, flirtatious, frivolous, excitable.

Berdasarkan persepsi mahasiswa dari etnis Jawa, terdapat sejumlah stereotip yang diposisikan untuk wanita dan sejumlah yang lain diposisikan untuk laki-laki, sebagai berikut. Pertama, stereotip untuk perempuan: critical parent, adult, achievement, exhibition, endurance, passive, weak, nurturing parent, adapted child, abasement, succorance, affiliation, appreciative, jolly, steady, gentle, boasful, favorability, order, softhearted, changeable, meek, affctionate, dependent, complaining, fussy, talk active, exitable. Kedua, stereotip untuk laki-laki: strong, dominance, autonomy, aggression, free child, deference, coarse, adventurous, cruel, disorder, loud, heterosexual, severe, logical, gentle, interception, flirtatious, frivolous.

Berdasarkan persepsi mahasiswa dari etnis Betawi, terdapat sejumlah stereotip yang diposisikan untuk wanita dan sejumlah yang lain diposisikan untuk laki-laki, sebagai berikut. Pertama, setereotip untuk perempuan: critical parent, adult, achievement, exhibition, endurance, passive, weak, adapted child, succou- rance, affiliation, jolly, gentle, favorability, order, appreciative, softhearted, changeable, meek, affectionate, dependent, complanining, fussy, talk active, frivolous, exitable. Kedua, stereotip untuk laki-laki: strong, dominance, autonomy, aggression, free child, deference, affilation, coarse, adventurous, cruel, disoder, loud, independent, heterosexual, boasful, severe, enterprising, confident, logical, steady, affected, interception, flirtatious.

Berdasarkan persepsi mahasiswa dari etnis Madura, terdapat sejumlah stereotip yang diposisikan untuk wanita dan sejumlah yang lain diposisikan untuk laki-laki, sebagai berikut. Pertama, setereotip untuk perempuan: critical parent, achievement, exhibition, endurance, passive, weak, sucorance, adapted child, affiliation, gentle, steady, favorability, order, appreciative, softhearted, changeable, meek, affectionate, dependent, complaining, fussy, talk active, exitable. Kedua, stereotip untuk laki-laki: strong, adult, dominance, autonomy, aggression, achievement, nurturing parent, free child, abasement, deference, affiliation, coarse, adventurous, cruel, disorder, loud, independent, heterosex, boastful, severe, enterprising, confident, logical, steady, affected, interception, flirtatious, frivolous, excitable.

\section{Stereotip Laki-Laki dan Perempuan Menurut Persepsi Mahasiswa Sepuluh Etnis}

Dari lima puluh buah ajektiva yang dijadikan alat pengungkap stereotip laki-laki dan perempuan, terdapat sejumlah ajektiva yang sesuai dengan persepsi mahasiswa dari sepuluh etnis dalam penelitian ini sebagai representasi stereotip laki-laki dan perempuan. Stereotip yang dimaksud adalah sebagai berikut.

Dari tabel 1 diketahui bahwa terdapat dua puluh enam buah ajektiva yang disetujui oleh mahasiswa dari sepuluh etnis di Indonesi. Dengan demiki- 
Tabel 1. Stereotip Laki-laki dan Perempuan yang Disetujui Mahasiswa Sepuluh Etnis

\begin{tabular}{cc}
\hline Ditujukan pada Laki-laki & Ditujukan pada Perempuan \\
\hline Strong & Exhibition \\
Dominance & Endurance \\
Autonomy & Passive \\
Aggression & Weak \\
deference & Abasement \\
coarse & Favorability \\
adventurous & Order \\
cruel & Softhearted \\
Disorder & Meek \\
Loud & Affectionate \\
Severe & Fussy \\
Logical & Talk active \\
Interception & \\
Flirtatious & \\
\hline
\end{tabular}

Tabel 2. Stereotip Laki-laki dan Perempuan yang Disetujui oleh Semua Responden

\begin{tabular}{cc}
\hline Ditujukan pada Laki-laki & Ditujukan pada perempuan \\
\hline Active & Weak \\
Strong & Nurturing parent \\
Critical parent & Adapted child \\
Adult & Abasement \\
Achievement & Deference \\
Autonomy & Passive \\
Aggression & Sucorance \\
Exhibition & Affiliation \\
Dominance & Heterosexuality \\
\hline
\end{tabular}

an, terdapat empat belas stereotip lakilaki dan dua belas stereotip perempuan yang direpresentasikan oleh ajektiva tersebut, yang sesuai dengan persepsi mahasiswa dari etnis Jawa, Sunda, Bali, Madura, Lombok, Batak, Minangkabau, Papua, Aceh, dan Betawi.

\section{Perbandingan dengan Penelitian Beest dan Williams}

Dari penelitian Beest dan Williams mengenai stereotip laki-laki dan perempuan, diketahui sejumlah stereotip yang disetujui oleh responden dari dua puluh lima negara. Berikut stereotip yang dimaksud. 
Berdasarkan tabel 1 dan 2 diketahui adanya persamaan dan perbedaan stereotip laki-laki dan perempuan yang disetujui oleh kelompok responden dari masing-masing penelitian. Persamaan dan perbedaan tersebut dapat dijelaskan sebagai berikut. Pertama, stereotip yang ditujukan pada laki-laki, seperti terlihat pada tabel 1 dan 2, adalah strong, dominance, autonomy, and aggression. Kedua, stereotip yang ditujukan pada perempuan, seperti terlihat pada tabel 1 dan 2 , adalah passive, weak, and abasement. Ketiga, stereotip yang ditujukan pada laki-laki, seperti terlihat pada tabel 1 tetapi tidak terlihat pada tabel 2, adalah deference, coarse, adventurous, cruel, disorder, loud, severe, logical, interception, flirtatious. Keempat, stereotip yang ditujukan pada laki-laki, seperti terlihat pada tabel 2 tetapi tidak terlihat pada tabel 1 , adalah critical parent, adult, exhibition, achievement, and endurance. Kelima, stereotip yang ditujukan pada perempuan, seperti terlihat pada tabel 1 tapi tidak terlihat pada tabel 2, adalah exhibition, endurance, favorability, order, softhearted, meek, affectionate, fussy, talk active. Keenam, stereotip yang ditujukan pada perempuan, seperti terlihat pada tabel 2 tapi tidak terlihat pada tabel 1, adalah nurturing parent, adapted child, deference, succorance, affiliation, heterosexuality. Ketujuh, stereotip yang ditujukan pada laki-laki pada tabel 1, tetapi ditujukan pada perempuan pada tabel 2, adalah deference. Kedelapan, stereotip yang ditujukan pada perempuan pada tabel 1 , tetapi ditujukan pada

Penstereotipan atau pelabelan yang diberikan pada laki-laki dan perempuan yang dilakukan masyarakat dipengaruhi oleh faktor sosiokultural. Persepsi masyarakat dibentuk melalui rasa akan segala sesuatu yang terjadi di lingkungan sekitar, yang membuat lakilaki pada tabel 2, adalah exhibition dan endurance. sesuatu hal harus direalisasi- kan dan terjadi di sekelilingnya. Mahasiswa adalah anggota dari masyarakat, yang melakukan penstereotipan atau pelabelan terhadap laki-laki dan perempuan di lingkungannya dari waktu ke waktu. Sebagai anggota masyarakat, mahasiswa dipengaruhi oleh latar budaya, dimana mahasiswa tersebut berasal. Latar budaya tersebut antara latar belakang keluarga, etnis, idiologi, dan lain sebagainya.

Keberagaman budaya, yang dalam penelitian ini direpresentasikan oleh sepuluh etnis di Indonesia, yaitu etnis Jawa, Sunda, Bali, Madura, Lombok, Batak, Minangkabau, Papua, Aceh, dan Betawi, menjadi latar belakang budaya yang mempengaruhi cara hidup mahasiswa. Selain itu, latar belakang etnis ini juga ikut mewarnai persepsi mahasiswa mengenai stereotip laki-laki dan perempuan. Hasil penelitian menunjukkan bahwa berdasarkan semua item yang ada dalam instrumen, tidak ada satupun persepsi tentang stereotip laki-laki dan perempuan yang sama persis antar kelompok mahasiswa dengan latar budaya etnis masing-masing. Dengan kata lain, keberagaman budaya akan membawa keberagaman pola penstereotipan terhadap laki-laki dan perempuan.

Walaupun demikian, di antara keberagaman etnis dan keberagaman persepsi mengenai stereotip laki-laki dan perempua yang ada pada diri mahasiswa diketahui adanya titik temu, yaitu adanya sejumlah stereotip lakilaki dan perempuan yang disetujui oleh mahasiswa dari semua etnis yang menjadi latar budayanya. Berdasarkan prosentase jawaban yang diberikan mahasiswa, terdapat empat belas stereotip yang dilabelkan pada laki-laki yaitu strong, dominance, autonomy, aggression, coarse, adventurous, cruel, disorder, loud, severe, logical, interception, and flirtatious. Selain itu, terdapat dua belas stereotip yang diposisikan kepada perempuan, 
yaitu exhibition, endurance, passive, weak, abasement, favorability, order, softhearted, meek, affectionate, fuss, and talk active.

Dari uraian di atas, diketahui pula bahwa sejumlah stereotip juga disetujui masyarakat Indonesia pada umumnya hingga saat ini. Strong, dominance, dan logical diposisikan untuk laki-laki, sedangkan weak, passive, dan talk active diposisikan untuk perempuan.

Weak dan passive yang dilabelkan kepada perempuan oleh semua mahasiswa dari semua etnis, sangat menarik untuk didiskusikan. Seperti diketahui, selama ini beriringan dengan isue tentang pemberdayaan wanita dan kesetaraan gender yang didengungkan pada setiap kesempatan, antara lain di forum ilmiah dan di media masa, stereotip lemah dan pasif yang ditujukan pada perempuan sepertinyaa sudah tidak 'disetujui' lagi, bahkan ingin 'dihapus'. Namun demikian, melalui penelitian ini dibuktikan bahwa stereotip lemah dan pasif masih dilekatkan pada perempuan, setidaknya menurut persepsi mahasiswa dari sepuluh etnis di Indonesia, yaitu etnis Jawa, Sunda, Bali, Madura, Lombok, Batak, Minangkabau, Papua, Aceh, dan Betawi. Hal ini didukung pula oleh hasil penelitian Beest dan Williams yang memiliiki responden dari dua puluh lima Negara, dan mewakili lima benua. Penelitian dengan responden yang sangat luas ini mengungkapkan bahwa weak dan passive yang dipilih responden sebagai stereotip perempuan. Untuk kawasan asia, hasil penelitian mengenai hal ini direpresentasikan oleh responden yang berasal dari negara Jepang, Taiwan, Thailand, Malaysia, dan India. Walaupun demikian, semua responden dari semua Negara menyetujui bahwa stereotip lemah dan pasif yang dilekatkan pada perempuan tidak bisa diasumsikan bahwa stereotip tersebut akan berlaku sepanjang masa.

\section{SIMPULAN}

Hasil penelitian dapat disimpulkan sebagai berikut. Pertama, mahasiswa dari semua etnis, baik laki-laki maupun perempuan, menyetujui bahwa terdapat persepsi tentang stereotip laki-laki dan perempuan yang bervariasi. Berdasarkan prosentase jawaban responden disetujui adanya stereotip yang dilekatkan baik pada laki-laki maupun perempuan. Kedua, terdapat sejumlah stereotip baik yang dilekatkan pada laki-laki maupun perempuan, yang disetujui oleh mahasiswa dari semua etnis. Stereotip yang dilekatkan pada laki-laki adalah strong, dominance, autonomy, aggression, deference, coarse, adventurous, cruel, disorder, and loud, severe, logical, interception, flirtatious. Adapun stereotip yang dilekatkan pada perempuan adalah passive, weak, abasement, exhibition, endurance, favorability, order, softhearted, meek, affectionate, fussy, and talk active. Ketiga, stereotip yang dilekatkan pada laki-laki menurut hasil penelitian ini dan penelitian Beest dan Williams adalah strong, dominance, autonomy, and agrression. Adapun stereotip yang dilekatkan pada perempuan menurut kedua penelitian adalah passive, weak, and abasement.

\section{UCAPAN TERIMA KASIH}

Akhirnya, kami sampaikan ucapan terima kasih kepada berbagai pihak yang telah mendukung terselenggarakannya penelitian ini, dari awal hingga akhir. Pertama, ucapan terima kasih disampaikan kepada Direktur DP2M Dikti yang menyeponsori penelitian ini dengan menghibahkan dana lewat program penelitian Kajian Wanita. Kedua, ucapan terima kasih disampaikan kepada Rektor UNY lewat Ketua Lembaga Penelitian UNY yang telah memfasilitasi penelitian ini sehingga dapat berjalan sesuai dengan rencana yang disepakati bersama. Selanjutnya, ucapan terima kasih disampaikan kepada teman seja- 
wat, responden, staf administrasi Lemlit UNY, dan berbagai pihak yang tidak bisa disebutkan satu per satu.

\section{DAFTAR PUSTAKA}

Abu, Zayd.2003. Dekonstruksi Gender Kritik Wacana Perempuan dalam Islam. Yogyakarta : SAMHA

Bart, Paulinzkowitz B. 1991. 'Feminist Theories' Henry Etzkowitz \& Ronald M. Glasman (ed.) The Renascence of Sociological Theory. Itasca: F.E Peacock Publishers Inc.

Best, Deborah L, Williams John E. 1993. "A Cross-Curtural Viewpoint". Anne E. Beall \& Robert J. Sternberg (ed.) The Psychology of Gender. New York: Guilfort Press.
Fakih, Mansur. 2003. Analisis Gender dan Transformasi Sosial. Yogyakarta: Pustaka Pelajar.

Gula, Dali. 1982. Kamus Psikologi. Bandung : Tonis.

Kridalaksana, Harimurti. 1996 Pembentukan Kata dalam Bahasa Indonesia. Jakarta: Gramedia.

Poedjosoedarmo, Soepomo. 2001. "Bahasa dan Pluralisme Budaya." Seminar Nasional. Bahasa, Sastra, dan Seni dalam Perspektif Pluralisme Budaya. Yogyakarta

Wardhaugh, R.1990. An Introduction to Sociolinguistic. Massachutset: Black Well. 